\title{
A Contribution to our Knowledge of Lyginodendron.
}

BY

\author{
A. C. SEWARD, M.A., F.G.S.
}

With Plates V and VI.

\begin{abstract}
A
MONG a number of specimens in the Botanical DepartDadoxylon, I found one transverse section which had been cut from a thick stem possessing a large pith and a considerable development of secondary wood. An examination of the specimen revealed certain striking anatomical characters entirely at variance with those of Dadoxylon or Cordaites, but on the other hand indicative of a close affinity with the genus Lyginodendron. The section had been taken from an unusually fine piece of fossil wood partially enclosed in argillaceous limestone, having a length of $\mathrm{I} 4 \mathrm{~cm}$. and a breadth of $14 \mathrm{~cm}$. A portion of the exposed surface of the specimen consists of smooth and waterworn wood; and where the fossil is enclosed by the surrounding matrix no trace of tissues external to the wood can be detected.

The wood measures $5.8 \mathrm{~cm}$. in the thickest part, and very probably when the stem was living it attained a still greater breadth, as there is no proof that the outermost portion as shown in the fossil represents the extent of the original woody tissue. The large pith lying towards one side of the block

[Annals of Botany, Vol. XI. No. XLI. March, 1897.]
\end{abstract}


measures $2.9 \mathrm{~cm}$. in the widest part. Seen in longitudinal section, the pith shows here and there somewhat irregular and more or less transverse bands of dark-coloured tissue which, on superficial examination, resemble the horizontal disks of the pith of Cordaites (Pl. V, Fig. 2). Other sections of the same block were afterwards found in the Museum, and finally additional preparations were recognized in the Williamson Collection as having been obtained from the large piece of stem. From the entries in Professor Williamson's Catalogue of microscopic sections it was found that the material came from the Coal-Measures of Oldham, and had been contributed by Mr. Nield. The specimen when intact must have been one of the largest ever found in the English Coal-Measures in which the internal structure had been preserved.

In the fourth of the series of Memoirs on the 'Organization of the Fossil Plants of the Coal-Measures', Williamson writes as follows with regard to a specimen referred to Lyginodendron: 'I have obtained from Mr. Nield one magnificent axis in which the woody cylinder and its contained medulla has been at least eighteen inches in circumference. The thickness of the wall of this vascular cylinder has been at least $2 \frac{1}{2}$ inches ; and, since the specimen is weathered and waterworn, it may have been of even larger dimensions.' In a foot-note the specimen is said to have been 'found in a watercourse intersecting the Lower Coal-Measures at a locality near Oldham known as Har Culver (Higher Culvert) ${ }^{1}$ '. In the recent memoir on Lyginodendron and Heterangium by Williamson and Scott, the authors refer more than once to Nield's large specimen. Discussing the size of Lyginodendron stems, these authors write: 'The largest undoubted stem of Lyginodendron which we possess attained a diameter of about $4 \mathrm{~cm}$. We leave out of consideration for the present both Mr. Nield's specimen and the cortical impressions. These must have belonged to stems of enormously greater size, but

${ }^{1}$ Phil. Trans., I 873 , p. 386 . A radial section of this specimen is figured in Plate XXIII, Fig. 9 (No. II 83 in the Williamson Collection). 
we cannot absolutely prove their identity with Lyginodendron ${ }^{1}$.' On page 742 of the same work we find the following account of the large Oldham fossil :-

'There remains the large specimen showing structure, received from Mr. Nield, and referred to in Memoir IV. p. $3^{86}$. The specimen includes the pith and a portion of the wide zone of secondary wood. Sections in the three directions have been cut and clearly exhibit the structure so far as it is preserved. The diameter of the pith is $3.3 \times 2.3 \mathrm{~cm}$. The maximum radial thickness of the secondary wood is $5.8 \mathrm{~cm}$., but we cannot be certain that its whole thickness is preserved. Assuming, however, that we have the whole thickness of the wood, the radius of the stem up to the cambium would have been over $7 \mathrm{~cm}$., and its diameter over $14 \mathrm{~cm}$. We cannot tell what was the diameter of the whole stem, for we know nothing of the cortex. No authentic specimen of Lyginodendron which we have seen, however, has secondary wood of a greater thickness than about $6 \mathrm{~mm}$.; so, if we judge by this dimension, the stem in question must have been nearly ten times as large as that of any undoubted Lyginodendron in the Williamson Collection. Unfortunately, the only structure preserved is that of the secondary wood. Its general anatomy is identical with that of certain specimens of Lyginodendron. The tracheids are smaller than is usual in Lyginodendron, but not smaller than in some undoubted stems of that plant. The radial section shows the muriform rays and the pits on the walls of the tracheids, which, in so far as their preservation allows of comparison, agree very well with those of our plant. The pith is completely disorganized, and no trace of the primary wood can be recognized. There is, however, a narrow incomplete zone of internal secondary wood, distinct from the rest, at the margin of the pith, which recalls the anomalous medullary tissue sometimes found in Lyginodendron. Although the parenchyma of the pith has perished, the cavity contains clusters of dark brown cells, 
which are much like the sclerotic nests characteristic of the pith of Lyginodendron. 'On the whole, until some other fossil has been found which agrees better with this doubtful stem, we think there is a presumption that it really belonged to a Lyginodendron, or to some plant of the same type of structure ${ }^{1}$.'

An examination of additional sections cut from Mr. Nield's specimen has furnished a few more facts as to the anatomical structure, and the main object of the present paper is to amplify and illustrate by means of a few figures the description given by Williamson and Scott. The material on which the following account is based consists of ( 1 ) the water-worn block mentioned by Williamson in 1873 , and now in the Botanical Department of the British Museum; (2) twelve sections in the Botanical Department; and (3) the following sections in the Williamson Collection ${ }^{2}$ (British Museum), viz. Nos. I I 3 I, I I 32, II 33 , II 83 , II 84 , I 85 . All the sections have been cut from the single specimen supplied to Professor Williamson by Mr. Nield. In P1. V, Fig. I, is represented a photographic reproduction of a transverse section. The diameter of the pith and wood has already been given. The large pith is seen to be partially occupied by irregular patches of tissue, which in longitudinal section (Fig. 2) assume the form of broken transverse bands. The inner margin of the secondary wood consists of small dark bands separated by lighter radially-elongated spaces. This is more clearly seen in Fig. 6 and in the lower part of Fig. 3; the lighter and broader patches were originally occupied by medullary-ray tissue, and the darker lines represent the internal limits of rows of secondary tracheids. In Fig. I, and more clearly in Fig. 6, the continuity of the inner margin of the wood is interrupted at three points, $t, t^{\prime}$, and $t^{\prime \prime}$, which mark the position of outgoing groups of xylem-elements, probably leaf-trace bundles ${ }^{3}$.

1 Phil. Trans., Vol. I86 (I895) B, p. $74^{2}$.

2 There are also two small sections in a collection of fossil plants in the Botanical Museum, Cambridge.

3 These groups of tracheids in passing through the secondary xylem of the stem 
The dark concentric lines seen in a transverse section of the wood, and especially well marked on the right-hand side of the photograph (Fig. I), are for the most part due to the occurrence of lines of narrower tracheids, locally developed in response to some influence which was much too irregular to be the result of seasonal changes. In Fig. 2 the wood and pith are shown in radial section; the mottled appearance of the former is due to the numerous and large medullary rays which form a characteristic feature of the stem. In Figs. 3 and 4 the character of the wood is more clearly seen; the lower end of Fig. 3 is in the immediate neighbourhood of the inner limit of the wood, and here the tracheids are fewer in number and farther apart than in the more external portion of the wood. The spaces between the narrow and curved rows of tracheids correspond to those seen less distinctly in Figs. I and $6:$ in this region of the stem the medullary-rayparenchyma has usually disappeared.

The xylem is entirely composed of tracheids with reticulately-pitted radial walls (Fig. 5); the nature of the pitting on the tracheids which form the innermost limit of the wood cannot be clearly seen owing to imperfect preservation. The xylem-elements are arranged in radial rows varying in breadth from one row of tracheids to bands composed of eight rows. In tracing bands of tracheids towards the periphery of the stem the number of elements composing any one band in a tangential direction is found to vary considerably, as the result of the intercalation of new rows or of a fusion between adjacent bands. The medullary rays consist of radially elongated parenchymatous cells of one to ten rows in breadth, the average breadth of a ray being nearly equal to that of the tracheidal bands. The broad medullary rays give to the wood the characteristic appearance noticed in the description of Fig. 2. Towards the inner margin of this wood the medullaryray-cells are usually absent, but in places where they have been preserved they are found to be tangentially elongated follow a gradually ascending and steep course, very similar to that of the leaf-trace bundles of Lyginodendron Oldhamium. 
between the widely separate bands of xylem. In Figs. 7 and 8 the wood is shown in tangential and radial section; in the former the polygonal cells of the medullary rays are seen to occupy long and narrow meshes, usually with pointed ends, in a framework of tracheids. No trace of bordered pits has been noticed in the tangential walls of the wood-elements. In radial section (Fig. 8) the reticulate pitting is found to be fairly well preserved, but the borders of the pits are for the most part imperfect (Fig. 5); the medullary-ray-cells present the characteristic appearance of radially-elongated parenchymatous cells, with here and there dark patches suggesting the contents of secretory cells. Seen under a higher power, the radial walls of many of the tracheids are found to be traversed by sets of parallel and obliquely running lines. It is difficult in many cases to determine how far such parallel markings on the xylem-elements of fossil plants are the result of cleavage in the infiltrated mineral substance, or to what extent they are the expression of some histological feature. In the tracheids of fossil coniferous wood we frequently find delicate and regular lines agreeing very closely in appearance with the striation characters of recent tracheids, and probably due to the emphasizing by ferment-action and decay of the original striations in the substance of the tracheid-walls. In the present instance it is probable that the lines referred to are in some measure due to the original striation of the tracheids.

The structures hitherto described in detail constitute the secondary centrifugally-developed wood. If the rows of tracheids in the secondary wood be traced to their inner termination, they are found to taper off to an acute apex, or to merge into a small group of tracheids in which the radial arrangement is either entirely absent or indistinctly marked. As already pointed out, the medullary-ray-cells have usually been destroyed in this region, and the spaces separating the inner terminations of the tracheid bands are often bounded by a fairly regular line, concave towards the pith; this marks the limit of decay, and recalls to some extent 
the appearance presented by the broad medullary rays of a Calamite stem (Pl. VI, Fig. IO). In the parenchymatous tissue internal to the tapered ends of the tracheid-rows, and to a less extent in the broad medullary-ray-tissues, there are found several patches of black substance which, no doubt, mark the position of secretory cells. Internal to the centrifugal xylem there extends round the periphery of the pith a series of short rows of tracheids, often arranged in groups with a fan-like disposition and with the apex facing the centrifugal wood. These series of tracheids are separated here and there by distinct medullary rays. This inner and much smaller zone of secondary tissue constitutes the centripetally-developed xylem. In Pl. V, Fig. 6, the faint line immediately internal to the centrifugal wood, and surrounding the pith, marks the position of the centripetally-developed tracheids; these are also semi-diagrammatically shown in P1. VI, Fig. 14x. In Pl. VI, Fig. 10, the inner limit of the centrifugal wood is shown on either side of a bay forming a break in the outer ring of xylem, and probably due to an outgoing leaf-trace-bundle. In P1. VI, Fig. I6, a fairly well preserved portion of the centripetal xylem is figured; it consists of rows of tracheids, sometimes as many as sixteen tracheids occurring in a single radial series, separated by bands of imperfectly preserved medullary-ray-parenchyma. The radial walls of these tracheids appear to have the same form of pitting as occurs in the centrifugally-developed xylem. Internally the centripetal ring is succeeded by very imperfectly preserved tissue, but in some places it can be readily seen that a merismatic layer existed on the pith-side of the inner ring of wood. The crushed and partially disorganized tissue internal to the wood contains numerous dark-coloured patches of tissue $(s)$ and an abundance of secretory cells. The former, of which one $(s)$ is shown in Fig. I6, internal to the centripetal wood, are nests of sclerous cells, of which several occur in the region of the pith (Fig. IO). In a longitudinal section the remains of phloem-tissues are found internal to the centripetal xylem, and in many places the 
tissues have been torn, apparently along the line of cambium, which gave rise to the centripetal xylem. Internal to the phloem a patch of medullary parenchyma is preserved, containing a sclerous nest and several black patches of secretory cell-contents.

Reserving for further consideration the nature and relations of the centripetal and centrifugal xylem, we may pass on to describe the pith. In Plate V, Fig. 2, the lighter portions in the pith mark the spots where the tissues have been destroyed and their place taken by mineral substance; the dark patches represent parenchymatous tissue containing numerous sclerous nests, which appear as dark dots in the photograph, and secretory cells. On examining transverse and longitudinal sections of the pith under a low magnifying power, one sees distinct signs of active merismatic division as expressed by the arrangement of parenchymatous cells in regular serial rows. Some of the darker portions in Fig. 2 consist of secondary parenchyma developed from a zone of meristem situated on the external limits of the darker-coloured and rounded outlines of the tissue-patches. In Fig. I 4 a portion of the pith is represented, very slightly enlarged; immediately internal to the centripetal wood there are patches of parenchymatous tissue containing secretory cells and three sclerous nests; internal to this, and separated from it by an intervening band of mineral matrix, we have a mass of parenchyma of which a considerable portion is made up of a series of regular radiating rows of elements formed by cambial activity, the cambium being situated at the inner edge of the secondary tissue $(c)$. This secondary medullary parenchyma presents the same appearance in longitudinal as in transverse sections.

In describing the occurrence of anomalous xylem in the pith of Lyginodendron Oldhamium, Williamson and Scott ${ }^{1}$ point out that in some cases the cambium gives rise to secondary parenchyma instead of xylem and phloem. The secondary parenchyma in the pith of Lyginodendron robustum is, on the

${ }^{1}$ Loc. cit., p. 722 . See also the reference on p. 723 to 'Some specially complicated forms of anomalous tissue in the pith of Lyginodendron Oldhamium.' 
other hand, a product of a meristem internal to the centripetal wood. A tissue of precisely similar appearance occurs in a specimen of Lyginodendron Oldhamium which Williamson figured in his Memoir IV (1873), Pl. XXII, Fig. $4^{1}$. The dark patches of tissue internal to the wood consist of radiallydisposed rows of parenchyma developed by a zone of cambium, and exactly corresponding in structure with the masses of tissue in the pith of Lyginodendron robustum. It is conceivable that the secondary parenchyma may be of a corky nature, and analogous to the periderm-tissue described in the pith of Stangeria paradoxa ${ }^{2}$ and in some stems of Bennettites ${ }^{3}$.

There remains to be considered the nature of the xylembands. Unfortunately the tissues between the outer edge of the centripetal xylem and the inner edge of the centrifugal xylem are very imperfectly preserved. In a few places, however, the two bands of wood are seen to be in direct continuity. The tracheids of the two zones of wood are frequently separated by a gap in the tissues; and, as previously noticed, the bands of centrifugal wood when traced to their inner termination often pass into groups of tracheids, which do not show anything of the regular arrangement characteristic of secondary xylem. In Plate VI, Fig. I2, and in Figs. 9 and $\mathrm{I} 6$, the characteristic appearance of the imperfectly mineralized tissue between the two sets of xylem-elements is represented. In one or two places between the centripetal and centrifugal wood, traces have been observed of tracheids showing indications of spiral thickening; it is possible that these may be the protoxylem-elements of the primary wood, but the preservation is hardly such as to justify any very decided statement.

This brings us to a comparison with the structure of the xylem as described by Williamson and Scott in Lyginodendron Oldhamium (Binney). In that species the centrifugally-

${ }^{1}$ No. II 53. Cf. also I I I 4, I I I 8 and other specimens in the Williamson Collection.

${ }^{2}$ Solms-Laubach, Bot. Zeit. Jahrg. 48, p. II.

${ }^{3}$ Capellini and Solms-Laubach. I Tronchi di Bennettitee (Mem. R. Accad. Sci. Inst. Bologna), Vol. ii, I89I, p. 48, Plate V, Figs. 2, 5 . 
developed secondary xylem agrees in the main very closely with that of the stem described above. On the inner side of the centrifugal wood there occur in Lyginodendron Oldhamium groups of primary xylem ; each group represents a leaf-tracebundle and possesses a well-defined mesarch structure, the position of the primary xylem-elements being recognized by the presence of the narrow spirally-thickened protoxylemtracheids, and the larger scalariform tracheids, in addition to the reticulately marked elements ${ }^{1}$. In some examples of Lyginodendron Oldhamium an inner zone of centripetal xylem has been described, probably identical with that in Nield's specimen. This inner xylem is described by Williamson and Scott as 'anomalous wood,' and compared with similar structures in certain recent Dicotyledons ${ }^{2}$. In attempting to establish the precise affinities of the stem under discussion it is extremely important to decide, as far as possible, whether or not there are any traces of primary xylem like that of Lyginodendron Oldhamium. Owing to the imperfect state of preservation in that part of the stem where the primary xylem should occur, it is very difficult to give a decided and satisfactory opinion as to the original existence of such primary groups as occur in the previously recorded examples of the genus.

It is, in the first place, conceivable that the primary xylemelements have become disorganized during the growth and increase in thickness of the stem. This possibility necessitates considerable caution in relying on negative evidence. On the other hand there are certain appearances presented by sections of Nield's stem which, without absolutely proving the existence of primary xylem-tracheids, render it probable that traces of such groups have been partially preserved. There are often found groups of tracheids, or occasionally single isolated tracheids, between the radially-disposed bands of centrifugal and centripetal wood. These, it may be, are portions of primary xylem-strands. The unfortunate imperfection in the

1 See the figures and descriptions in Williamson and Scott's paper.

2 Williamson and Scott, loc. cit., pp. 722, 723. 


\section{Knowledge of Lyginodendron.}

mineralization of the tissues in this region, renders it impossible to make use of such characters as the nature of the pitting as a distinguishing feature of the primary xylemtracheids. In Lyginodendron Oldhamium, for example, the scalariform character of the tracheids affords a convenient distinguishing feature of the primary xylem in longitudinal section. In one or two longitudinal sections imperfectly preserved tracheids have been detected of which the faint traces of pitting suggest the scalariform type, such as occurs in the primary xylem of Lyginodendron Oldhamium, but the evidence is insufficient to be cited as absolute proof.

In Plate V, Fig. 6 , at $t^{\prime}$ and $t^{\prime \prime}$, is shown a group of tracheids in contact laterally and distally with the main mass of centrifugal xylem; these groups are probably leaf-tracebundles on their way to the surface of the stem. In Plate VI, Fig. I 5 , a single leaf-trace is seen under a higher magnifying power; the dark lines indicate the direction of the rows of tracheids, and the centripetal xylem is represented at $x^{2}$. It is not possible to recognize at the proximal end of the outgoing leaf-trace-bundle any definite indication of primary xylem-elements; the space may be in part the result of tearing of the tissues in the immediate neighbourhood of the primary tracheids. In another section showing a leaf-tracebundle in a similar position to that represented in Fig. I5, there are groups of fairly thick-walled elements lying about internal to the fan-shaped trace; these may be portions of the primary xylem. At the distal end of a somewhat obliquely-cut leaf-trace, as seen in a transverse section of the stem, there is a mass of narrow and radially-elongated parenchymatous cells. In tangential sections of the stem the leaf-trace-bundles are seen passing through the centrifugal xylem, and in their immediate neighbourhood the tracheids of the wood exhibit extraordinary contortions. In Fig. I I some of the strongly curved centrifugal tracheids are shown in connexion with an outgoing leaf-trace ${ }^{1}$. One of the

\footnotetext{
1 A very similar appearance is presented by a tangential section of a Calamitean
} 
small sections (I 85 ) in the Williamson Collection shows the strongly marked curvatures of the tracheids remarkably well.

It has been pointed out by Williamson and Scott that in Lyginodendron Oldhamium the internal cambium may arise 'partly from the parenchyma of the primary xylem, so that some of the tracheae belonging to the latter have been carried inwards into the pith ${ }^{1}$ ' By this means the original position of the primary xylem-elements would be altered, and their subsequent recognition rendered more difficult. This possibility should be borne in mind in connexion with the apparent absence of primary xylem-strands in Nield's stem.

To compare, briefly, Lyginodendron Oldhamium and the larger stem described above, as regards the centrifugal wood, there is on the whole a very close agreement; but a careful comparison of sections from the British Museum stem with numerous examples of Lyginodendron Oldhamium confirms the opinion expressed by Williamson and Scott, that in Nield's specimen the tracheids are somewhat smaller than in the undoubted examples of Lyginodendron. In Lyginodendron Oldhamium the medullary rays are usually narrower, and smaller in proportion to the breadth of the tracheid-bands than in the larger stem. The anomalous wood described by Williamson and Scott in some examples of Lyginodendron is precisely similar in structure to the ring of centripetal wood in Nield's stem. In some examples of Lyginodendron Oldhamium the tissues of the pith present the same regular radial arrangement of parenchymatous cells as in the large stem. The sclerous nests and secretory sacs are practically identical in distribution and appearance in Lyginodendron Oldhamium and Nield's stem.

In transverse sections of Lyginodendron Oldhamium one occasionally finds that the secondary centrifugal wood and the primary xylem assume the appearance of an almost continuous band without any obvious division between them;

stem, figured by Renault in a 'Notice sur les Calamariées.' Autun, 1895, Plate IV, Fig. 6.

1 Loc. cit., p. 723. 
presenting, in fact, an appearance very similar to that already noticed in certain parts of the large stem ${ }^{1}$. Sections of Lyginodendron Oldhamium occasionally show an apparent continuity between the centrifugal and centripetal xylem-bands, the primary xylem being sometimes disturbed and much less obvious than in other parts of the section.

In the remarks on two sections (Nos. II 29 and II 30 ) written in the catalogue of the Williamson Collection, the great breadth of the medullary rays is pointed out; the secondary wood in the specimens is very similar to that in Nield's stem, but the tracheids in the former are slightly wider. The same sections show also the curving of the inner ends of the tracheid-bands, as in the large stem; the groups of primary xylem in these sections present a crushed appearance and are separated by wide intervals. The general appearance of the sections is exceedingly close to that of Nield's plant ${ }^{2}$. The comparison of several specimens of Lyginodendron Oldhamium with the stem under discussion, as regards the manner of occurrence of the primary xylem, renders it probable that the absence of any direct proof of the existence in the latter of undoubted primary elements by no means negatives the idea that the plant originally possessed primary xylem-strands similar to those of the former species. A tangential section through the wood of Lyginodendron Oldhamium presents the appearance of longer and narrower medullary rays than those represented in $\mathrm{Pl}$. V, Fig. 7 ; but although there is a fairly constant difference in this respect, by examining a sufficient number of sections it is possible to match fairly closely the various structures in the two sets of specimens.

The general conclusion arrived at may be briefly stated as follows. The large stem which forms the subject of the

1 e.g. No. 1150 in the Williamson Collection.

2 Williamson noticed the close resemblance in the wood of the two sections (II 29 and II 30 ) to that of Nield's specimen. In his catalogue he speaks of the wood and medullary rays of these two sections as practically proving the identity of Nield's specimen and Lyginodendron Oldhanium. 
present paper, should be placed in the genus Lyginodendron, but is in all probability not specifically identical with Lyginodendron Oldhamium (Binney). No actual proof of the occurrence of primary xylem-tracheids has been discovered, but such evidence as is available is favourable rather than opposed to the original existence of such primary strands. As a convenient designation of Nield's large stem, of which the diameter must have been very considerably greater than in any previously known specimen of the genus, we may adopt the name Lyginodendron robustum.

With reference to the numerous examples referred to Lyginodendron Oldhamium, Williamson and Scott write: 'All the forms with which we are concerned may be provisionally referred to the same species, or rather type, Lyginodendron Oldhamium.' As these words imply, it may be possible with more complete knowledge to recognize additional specific types among the numerous examples of the genus. As regards a comparison with recent plants, the most striking resemblance is that between the centrifugal wood of Lyginodendron robustum and the wood of Cycadean stems. An examination of sections of the secondary wood of Cycas, Stangeria, and Macrozamia reveals the closest possible resemblance with Lyginodendron. In the stems of Cycas and Macrozamia, however, the wood does not form a broad continuous band as in Lyginodendron robustum, but consists of concentric zones developed from successive meristems. The cycadean nature of the centrifugal wood of Lyginodendron Oldhamium has been previously pointed out by Williamson and Scott ${ }^{1}$ and others ${ }^{2}$, but the much larger size of the stem of $L y g i$ nodendron robustum makes the resemblance still more striking than in the much smaller form, Lyginodendron Oldhamium.

In 1879 Renault described a new type of a Palaeozoic plant from the well-known silicified beds of Autun, to which he gave the name Cycadoxylon Fremyi ${ }^{3}$. A comparison of

1 Loc. cit., p. 767 . $\quad 2$ Solms-Laubach, Fossil Botany (I 89I), p. 36r.

3 Structure comparée de quelques tiges de la Flore Carbonifère (Nouv. Arch. Mus. Paris, Vol. ii [2], 1879, p. 283. See also Cours de botanique fossile, Vol. i. (I880), p. 74, Plate XI. 


\section{Knowledge of Lyginodendron.}

the figures illustrating the structure of this Autun specimen with those of Lyginodendron robustum brings out a striking similarity as regards the structure of the centrifugal wood. The tangential section figured in Pl. V, Fig. 7, of the present paper is very similar to the corresponding section of Cycadoxylon (Renault, Pl. XIV, Fig. I2). There is also a close agreement between the transverse and radial sections of the wood of the two plants (cf. Renault, P1. XIV, Figs. Io and I I, and Lyginodendron robustum, Figs. 4, 8, 10, 16). More recently M. Renault has supplemented his earlier account of Cycadoxylon by additional figures and a further description published in an important work on the coal-field of Autun and Epinac.

The following description of the structure of the wood as seen in a transverse section of Cycadoxylon Fremyi illustrates the most striking characters: 'Le système ligneux est composé d'un cylindre extérieur continu d'arcs ligneux dispersés dans la moelle en nombre variable. Le cylindre extérieur est formé de séries rayonnantes de trachéides, ponctuées, à accroissement centrifuge; les bandes ligneuses intérieures sont constituées par des séries rayonnantes semblables, mais dont l'accroissement est centripète' ${ }^{1}$. Renault compares this genus, of which Cycadoxylon Fremyi is the only example, with Ptychoxylon and Medullosa. The centrifugal and centripetal bands of xylem are separated from one another by parenchymatous tissue, and there is no indication of any continuity between them in a radial direction, nor are there any groups of primary xylem internal to the centrifugal wood such as occur in Lyginodendron Oldhamium. Since writing this paragraph I have had an opportunity, through the kindness of M. Renault, of examining the sections of Cycadoxylon. In one specimen a small group of primary xylem was clearly shown.

In Fig. $5^{6}$ (p. 309) of the Flore fossile d'Autun et d'Épinac, a portion of a transverse section of Cycadoxylon

1 Bassin Houiller d'Autun et d'Épinac. Flore fossile, Pt. II, p. 307 . I am indebted to M. Renault for kindly forwarding me a proof of that part of his forthcoming work which deals with Cycadoxylon. [The text of this work has now appeared. January, 1897.] 
Fremyi is represented, showing an internal and narrow band of centripetal xylem, composed of tracheid-rows separated by broad medullary rays, and external to this a narrow zone of parenchyma, followed by a broader zone of centrifugal. xylem. The broad band of the latter wood consists of rows of tracheids and broad medullary rays practically identical with the corresponding xylem of Lyginodendron robustum, the centripetal wood is also precisely alike in the two plants. The absence of any cortical tissues in Lyginodendron robustum prevents any comparison with the cortex of Cycadoxylon. 'Gum-canals' are fairly numerous in the tissues of the latter genus, as in Lyginodendron.

In the pith of Cycadoxylon there appear to be no sclerous nests, and in the cortical tissues there are none of the radiallydisposed bands of sclerenchyma characteristic of Lyginodendron Oldhamium. As at present defined, the genus Cycadoxylon is no doubt distinct from Lyginodendron; the resemblance, which is indeed particularly close between the centrifugal and centripetal wood of the two plants, Cycadoxylon Fremyi and Lyginodendron robustum, is one based on secondary structures. There is no evidence of any similar agreement as regards the more important primary structures ${ }^{1}$.

In $18 ; 8^{2}$ Williamson figured and described three sections of a fragment of wood from the volcanic ash of Arran which he named Lyginodendron anomalum. A re-examination of the sections by Williamson and Scott led them to regard the specimen as having 'nothing in common with the genus Lyginodendron' but as rather comparable with Renault's Cycadoxylon ${ }^{3}$. In transverse section the Arran fragment shows bands of reticulately pitted tracheids and broad medullary rays, with some of the tracheids occasionally cut across in an obliquely longitudinal direction. In tangential section

1 The existence of a group of primary xylem, referred to in a previous footnote, makes the agreement still closer.

${ }^{2}$ Phil. Trans., I 878 (Memoir IX of Williamson), p. 252, Plate XXV, Figs. 90-92. The specimen from which the sections were obtained is in the Geological Museum of the University of Glasgow.

${ }^{3}$ Williamson and Scott, loc. cit., p. 770 (footnote). 
we have an irregular network of tracheids with the large meshes occupied by groups of polygonal parenchymatous cells. The tangentially-cut medullary rays assume the form of oval, circular, or oblong groups of cells, bounded by the extremely sinuous and contorted tracheids. The chief difference between the tangential section of Lyginodendron anomalum and Lyginodendron robustum consists in the broader and shorter medullary rays of the former, and the more irregular and sinuous course of the tracheids. In a section through the centrifugal wood of Lyginodendron robustum in the neighbourhood of an outgoing leaf-trace, the tracheids are similarly contorted to those in Lyginodendron anomalum. In a tranverse section of the former passing through a leaf-trace-bundle, as shown in P1. V, Fig. $6, t$ and $t^{\prime}$, and P1. VI, Fig. 15, the broad distal end of the trace is followed by long and narrow parenchymatous cells, which have accompanied the tracheids from the inner edge of the wood. The general appearance of such a section is almost identical with that of a transverse section of Lyginodendron anomalum. Such a comparison suggests the possibility that the shorter and broader medullary rays and the more irregular course of the tracheids may not represent the normal character of the stem from which the Arran fragment was obtained, but that these appearances may be the result of some disturbing influence in the secondary wood. The resemblance between Lyginodendron robustum and Lyginodendron anomalum as regards the structure of the wood and the form of the medullary rays, which is specially striking in the wood of the former species where the normal form of the rays is modified by the bending of the tracheids to a leaf-trace-bundle, points to the possibility of the two forms being closely allied to one another. The Arran fragment is much too small to allow of precise identification, but the structure of the wood renders it extremely probable that in Lyginodendron anomalum, Will., we have a small piece of a stem which possessed secondary wood of the cycadean type very similar in structure to that of Lyginodendron 
robustum and Cycadoxylon Fremyi. In the absence of more complete specimens, it is impossible to decide which of these generic names shall be adopted ${ }^{1}$; but the Arran plant may, I believe, be regarded as closely allied to Lyginodendron Oldhamium and Cycadoxylon Fremyi. The figure of a transverse section of Lyginodendron anomalum given by Williamson in his Memoir IX, Pl. XXV, Fig. 90, does not bear so close a resemblance to Lyginodendron robustum as is apparent in another section recently cut from the same specimen and now added to the Williamson Collection. In this section the broad medullary rays and bands of tracheids are more regular in their arrangement, and the section as a whole exhibits a striking similarity to that of Lyginodendron robustum. A small portion of this section is shown in Pl. VI, Fig. I 3 ; in some of the bands of tracheids the individual elements are occasionally cut across obliquely, but on the whole the structure is like that shown in the figure.

Without attempting to give a specific diagnosis, we may briefly summarize the more important characteristics of the specimen for which the name Lyginodendron robustum is suggested, and which has hitherto been spoken of as 'Nield's specimen.' The centrifugal wood is composed of reticulatelypitted tracheids somewhat smaller in diameter than those of Lyginodendron Oldhamium; the medullary rays are rather broader, and there is a more regular continuous zone of centripetal xylem than in Lyginodendron Oldhamium. In the latter plant this internal development of xylem is found to vary considerably in amount in different regions of the same transverse section. In the transverse section $1885 \mathrm{E}$ (Williamson Collection), the 'anomalous wood' is well shown, but internal to one of the primary xylem-strands it is absent.

This particular group of xylem is seen to be in direct continuity with the external centrifugal wood in such a

1 In addition to the sections in the Williamson Cabinet (No. I 208 and three others), there is a somewhat larger tangential section, apparently from the same specimen, in the Binney Collection (Cambridge). The original specimen is in the Hunterian Museum, Glasgow University. 
manner as to closely resemble the appearance presented by some of the sections of Lyginodendron robustum. Williamson and Scott do not attach the slightest importance to the anomalous medullary cambium as a specific character; they point out that 'among stems, which are perfectly similar in other respects, some show it and some do not, while in those that possess this anomaly, the degree in which it is developed is most variable "'

Numerous sclerous nests and secretory sacs occur in the pith of Lyginodendron robustum, and the latter are also present between the centrifugal and centripetal wood, and in the medullary-ray-tissue. An extended examination of several sections leads to the conclusion that Williamson and Scott's opinion that Nield's specimen 'really belonged to a Lyginodendron, or to some plant of the same type of structure,' is no doubt correct. Lyginodendron robustum represents by far the largest stem of the Lyginodendron type so far recorded, and the considerable thickness of the secondary xylem renders more obvious the close correspondence with the wood of recent cycadean stems, than is apparent in the much smaller stems of Lyginodendron Oldhamium.

In certain genera of fossil plants, one of the most prominent characteristics is the very close resemblance of their centrifugal xylem to the wood of recent Cycads. Lyginodendron, Heterangium and Cycadoxylon afford three examples of such agreement, and other genera might be mentioned. It is not unusual to discover specimens of plant-fragments in which the secondary xylem-characters are clearly preserved, but from which it is impossible to formulate a complete diagnosis.

It is often impossible to rely on the structure of the secondary wood alone as a means of specific or even generic identification; but the nature of the xylem-elements, the

${ }^{1}$ Loc. cit., p. 723. Examples of Lyginodendron Oldhamium showing an unequal development of centripetal wood are figured by Williamson (Mem. XVII. Phil. Trans., I890, Plate XIII, Fig. 3) and by Williamson and Scott (Phil. Trans., I 895, Plate XXIII, Fig. 8). Both sections were cut from the same specimen; also sections II 42 and $1885 \mathrm{E}$. 
structure and form of the medullary rays, usually enable us to refer a specimen to a definite family or group of plants. In dealing with coniferous wood we are able to adopt certain recognized generic designations, such as Araucarioxylon, Pityoxylon, and others, which, as somewhat comprehensive terms, are extremely useful in systematic work. The term Cycadoxylon proposed by Renault, if extended in its application, might serve as a general generic designation for plants possessing secondary xylem closely resembling that of recent Cycads. Such a term would be particularly useful in dealing with imperfect material; while the more complete data obtained from better specimens would enable us to make use of generic designations of a less comprehensive meaning.

In his important Memoir on the comparative structure of certain Coal-Measure stems, Renault includes the three genera Cycadoxylon, Colpoxylon, and Medullosa in the group Cycadoxyleae; and as a characteristic of the group he mentions that the genera in question have lost the centripetal wood in their stems, while retaining it in their leaves ${ }^{1}$. In the more recent, and fuller, account of Cycadoxylon, Renault figures and describes well-marked bands of centripetal wood, thus necessitating either a modification of the original definition of the Cycadoxyleae, or a removal of Cycadoxylon from that group of plants in which the stem has no internal centripetal wood.

If Cycadoxylon were adopted in a wider sense than as defined by Renault, it would be the more appropriate genus to which to refer Lyginodendron anomalum. In the case of Lyginodendron robustum alone it might perhaps be better to make use of this generic designation; but the presumptive evidence in favour of a generic identity with Lyginodendron Oldhamium is so strong, that there appear to be sufficient grounds for the choice of the more restricted genus Lyginodendron. Without attempting to institute a comparison with the various Palaeozoic genera possessing cycadean characters, 
it would seem that Lyginodendron robustum, Lyginodendron Oldhamium, Lyginodendron anomalum, and Cycadoxylon Fremyi, possess such characters in common as distinctly point to a close relationship.

Our incomplete knowledge of the last named species, as compared with our much more complete acquaintance with Lyginodendron Oldhamium, renders it unprofitable to press the comparison very far; but it is probable that we may be able, with more extended knowledge, to classify many of the Palaeozoic types into more definite groups founded on the true relationship as expressed by the possession of cycadean characters.

The structure of Medullosa gigas, Ren., as described in the Flore fossile d'Autun et d'Épinac, presents an exceedingly close agreement with that of Lyginodendron (Flor. foss., Pl. LXXI). A more complete comparison of the various Palaeozoic plants possessing cycadean affinities must, however, be deferred.

My thanks are due to Mr. George Murray, Keeper of the Botanical Department in the British Museum, for permission to have several sections prepared from material in his charge; to Mr. Gepp, of the British Museum, I am indebted for the photographs reproduced in Plate V; and to Dr. D. H. Scott for valuable criticisms and suggestions.

\section{EXPLANATION OF FIGURES IN PLATES $\mathrm{V}$ AND VI.}

Illustrating Mr. Seward's paper on Lyginodendron.

All the sections have been prepared from the same specimen of Lyginodendron robustum, sp. nov., and are in the Botanical Department of the British Museum.

PLATE V.

Fig. I. Transverse section of the stem, showing the thick centrifugal wood with apparent annual rings, and the tissues of the pith, with secondary parenchymatous tissue at $p$. 
Fig. 2 Longitudinal section (radial) showing the characteristic appearance of the wood as seen in radial section, and the imperfectly preserved tissues of the large pith. (Figs. IO2 are from photographs by Mr. Gepp, and represent approximately the natural size of the sections.)

Fig. 3. Portion of a transverse section of the centrifugal wood, with the broad medullary rays especially distinct at the lower end of the figure (from a photograph by Mr. Hayles of the Cavendish Laboratory, Cambridge). $\quad \times 17$.

Fig. 4. Portion of the wood of Fig. 3 more highly magnified, showing the broad medullary rays. $\times 5^{2}$.

Fig. 5. Radial wall of a tracheid of the centrifugal wood. $\times 320$.

Fig. 6 . The inner edge of the wood and the pith-parenchyma: $t, t^{\prime}, t^{\prime \prime}=$ leaftrace-bundles, $x^{2}=$ centripetal wood, $s=$ sclerous nests (natural size).

Figs. 7,8 . Tangential and radial longitudinal sections through the centrifugal wood. $\times 5^{2}$.

\section{PLATE VI.}

Fig. 9. Transverse section showing the inner termination of the centrifugal wood $\left(x^{1}\right)$, and the imperfectly preserved bands of centripetal tracheids $\left(x^{2}\right)$, and medullary rays. $\times 52$.

Fig. Io. Transverse section showing the characteristic tapered rows of tracheids at the internal limit of the centrifugal wood, separated by spaces left on decay of the broad medullary rays: $x^{2}=$ centripetal xylem, $s=$ sclerous nests (slightly enlarged).

Fig. I I. Tangential longitudinal section passing through the centrifugal wood in the immediate neighbourhood of a leaf-trace-bundle. The figure represents only a portion of the outgoing trace.

Fig. I2. Transverse section showing the inner ends of centrifugal tracheids and the outer limit of centripetal tracheids. $\times 5^{2}$.

Fig. I3. Lyginodendron anomalum. Transverse section. $\times 52$.

Fig. I4. Lyginodendron robustum. Slightly enlarged sketch of the inner edge of the xylem and the peripheral tissues of the pith ; $p=$ radially-arranged secondary parenchyma, $c=$ meristem ; $x^{1}=$ centrifugal, and $x^{2}=$ centripetal xylem ; $s=$ sclerous nests.

Fig. I5. Transverse section including a leaf-trace-bundle cut across somewhat obliquely, $*=$ space at proximal end of the leaf-trace (slightly enlarged).

Fig. 16. Transverse section to show the fairly well preserved centripetal xylem $\left(x^{2}\right) . \quad \times 5^{2}$. 
Annals of Botany

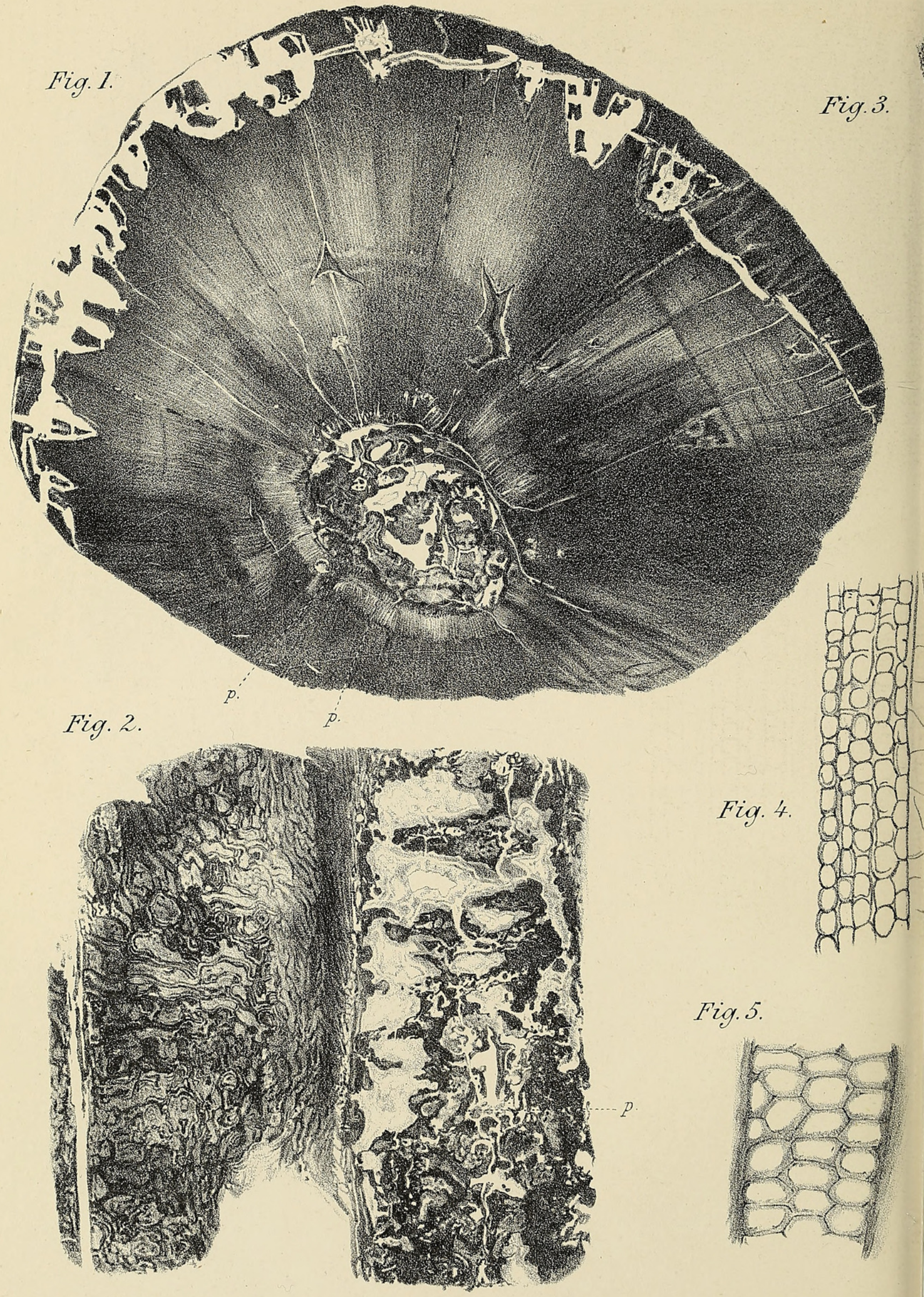

Fig. 1 \& 2, from photo. by A. Gepp.

Fis. . 4-8, A.C.Seward del.

SEWARD. - LYGINODENDRON. 
Vol. XI, PL.V.
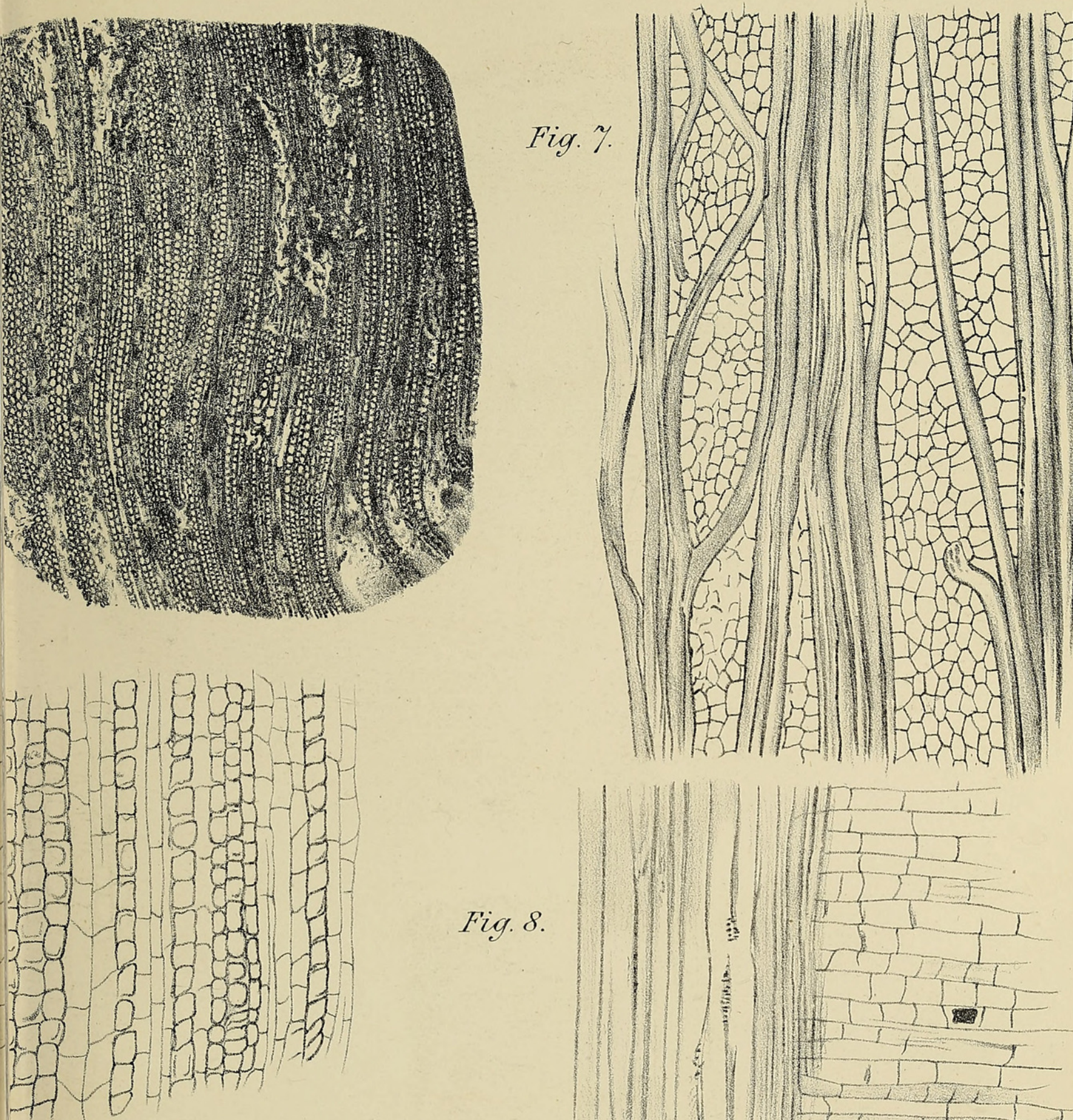

Fig. 8 .
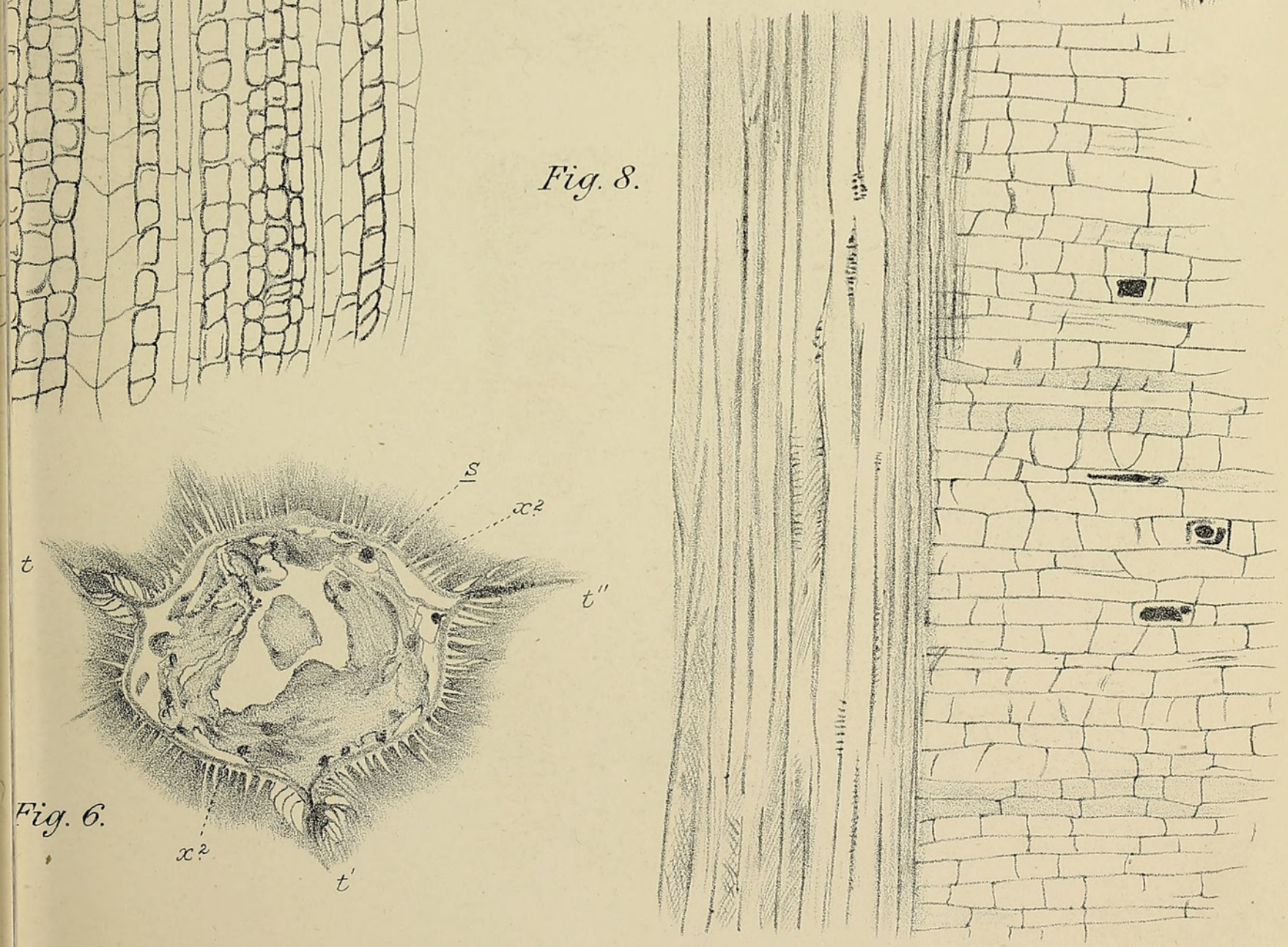

University Press, 0xford. 


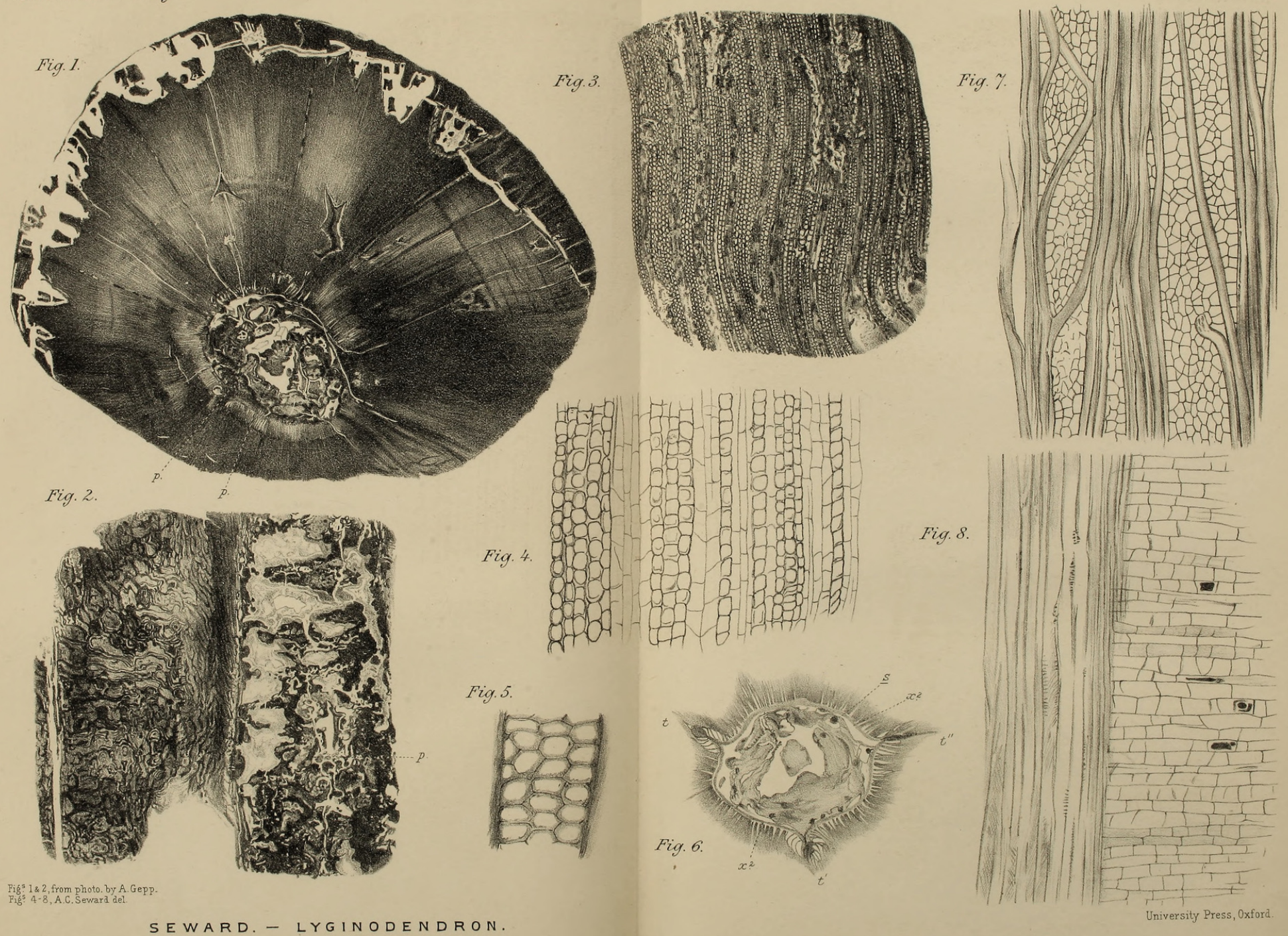


Annals of Botany

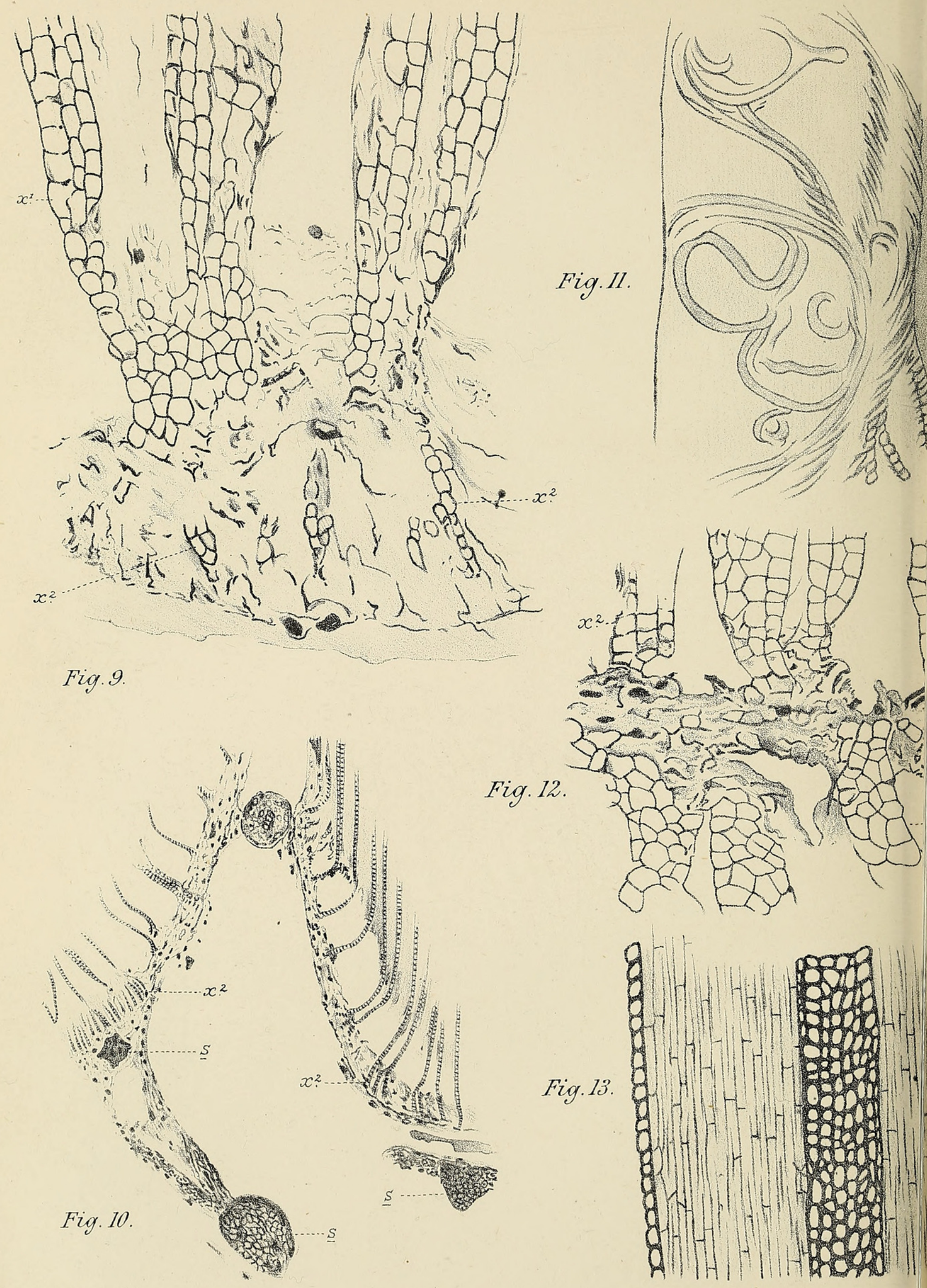


121

90
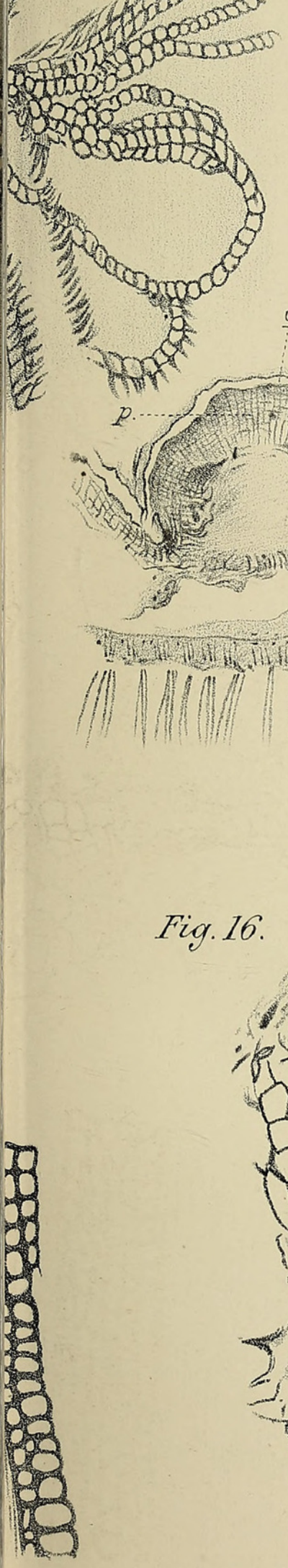

Fig. 15.

Fig. 14 .
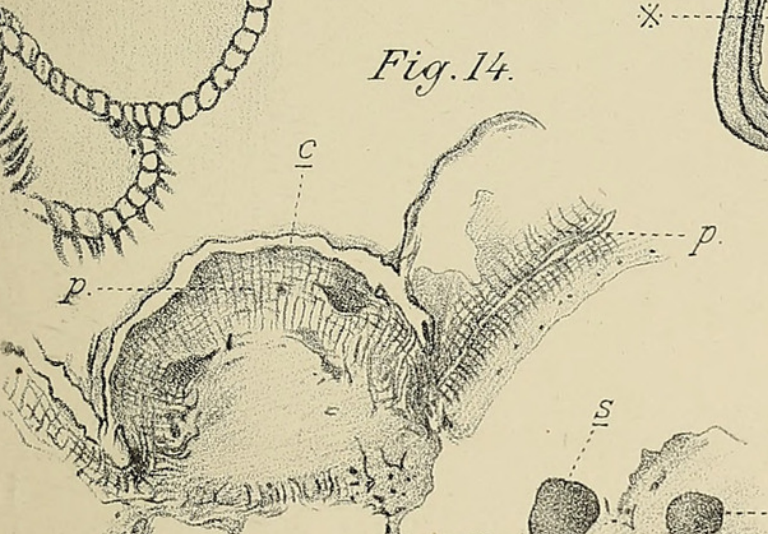

(1)

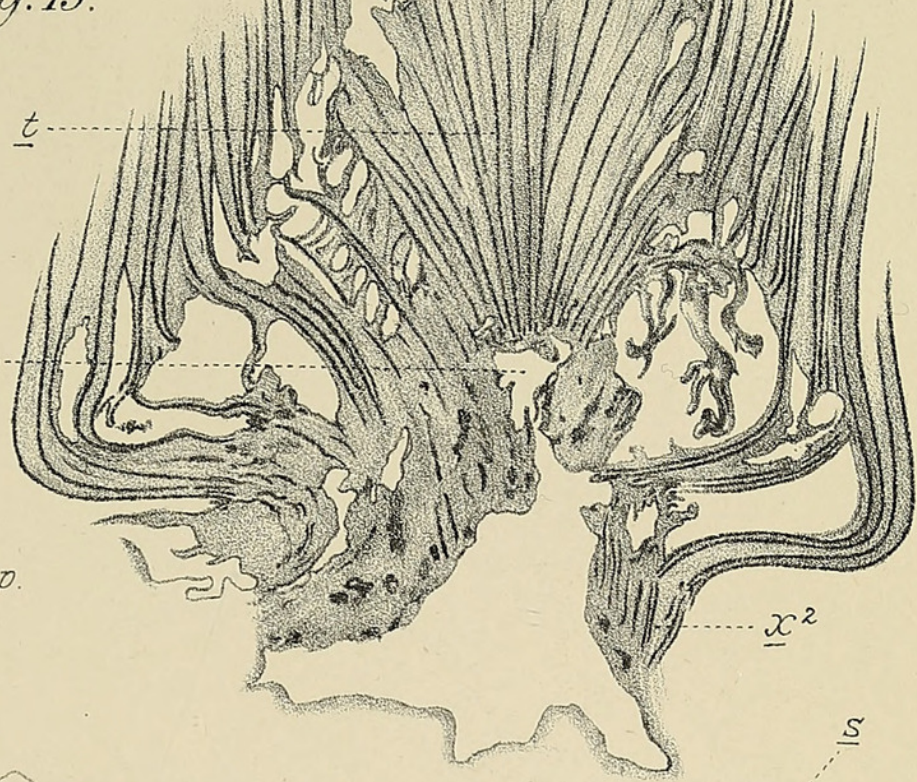

(1)
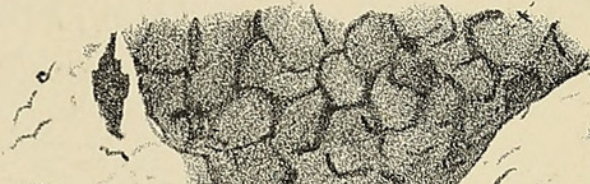

7 a nown

Fing. 16. 16.

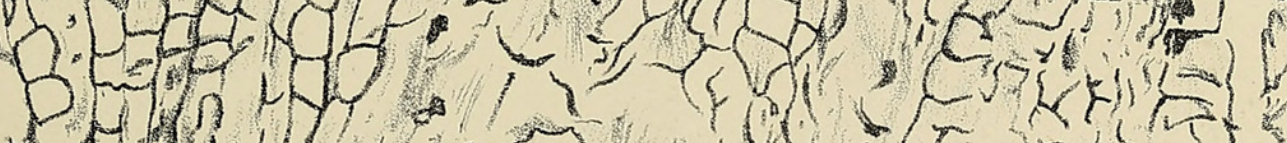

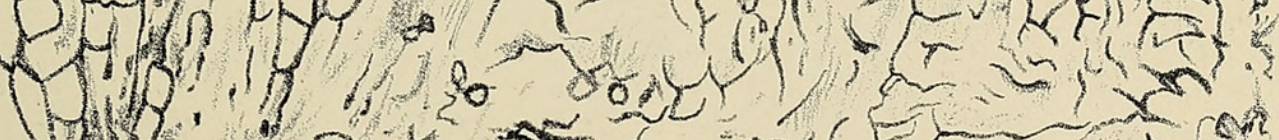

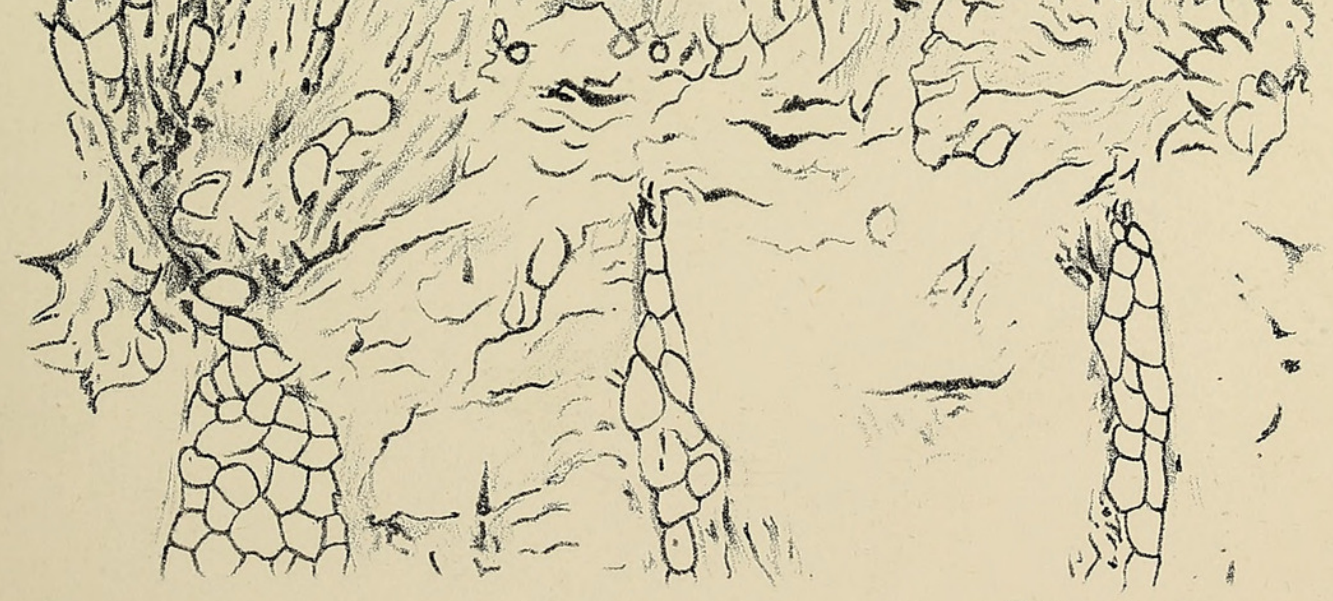



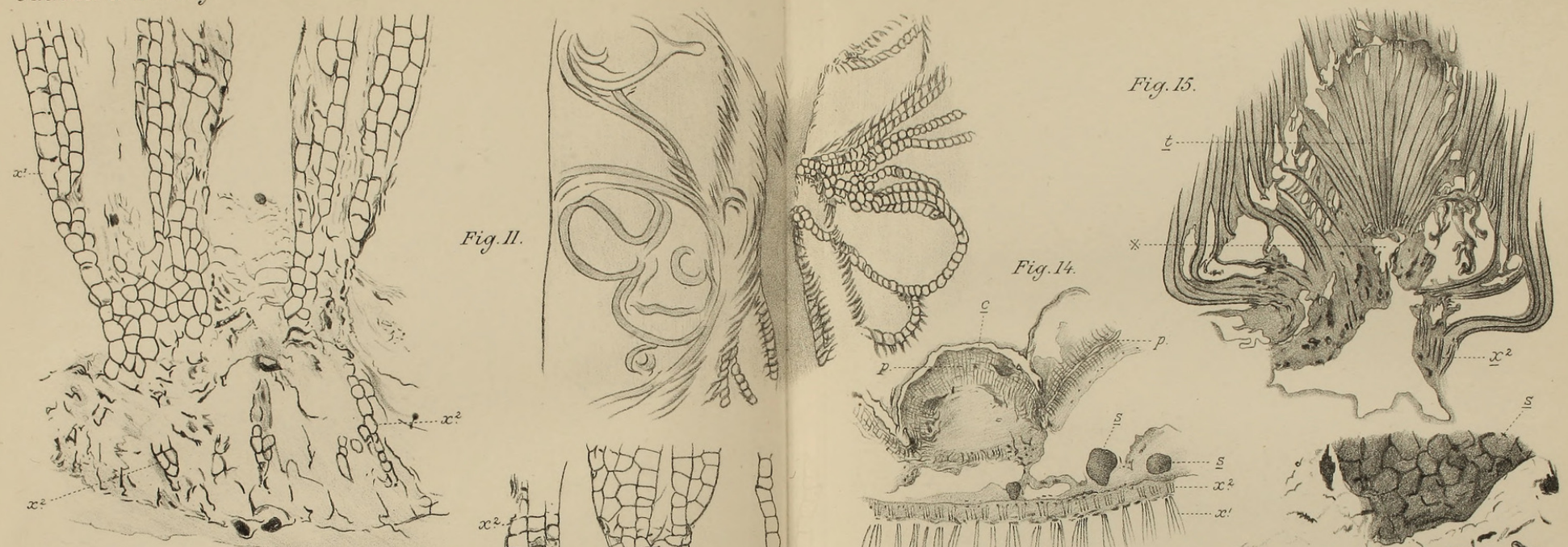

Fig. 9.
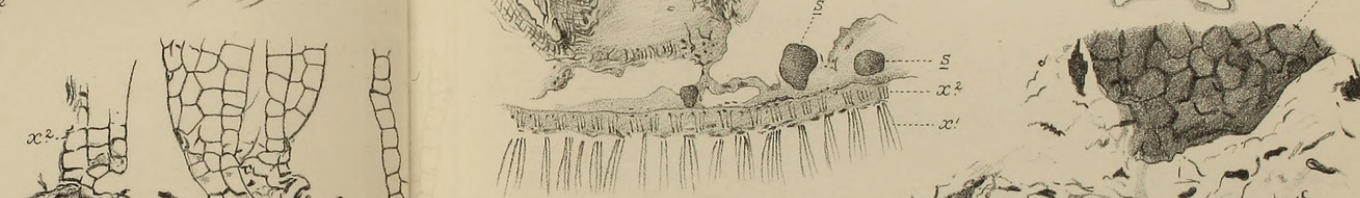

III IIIT
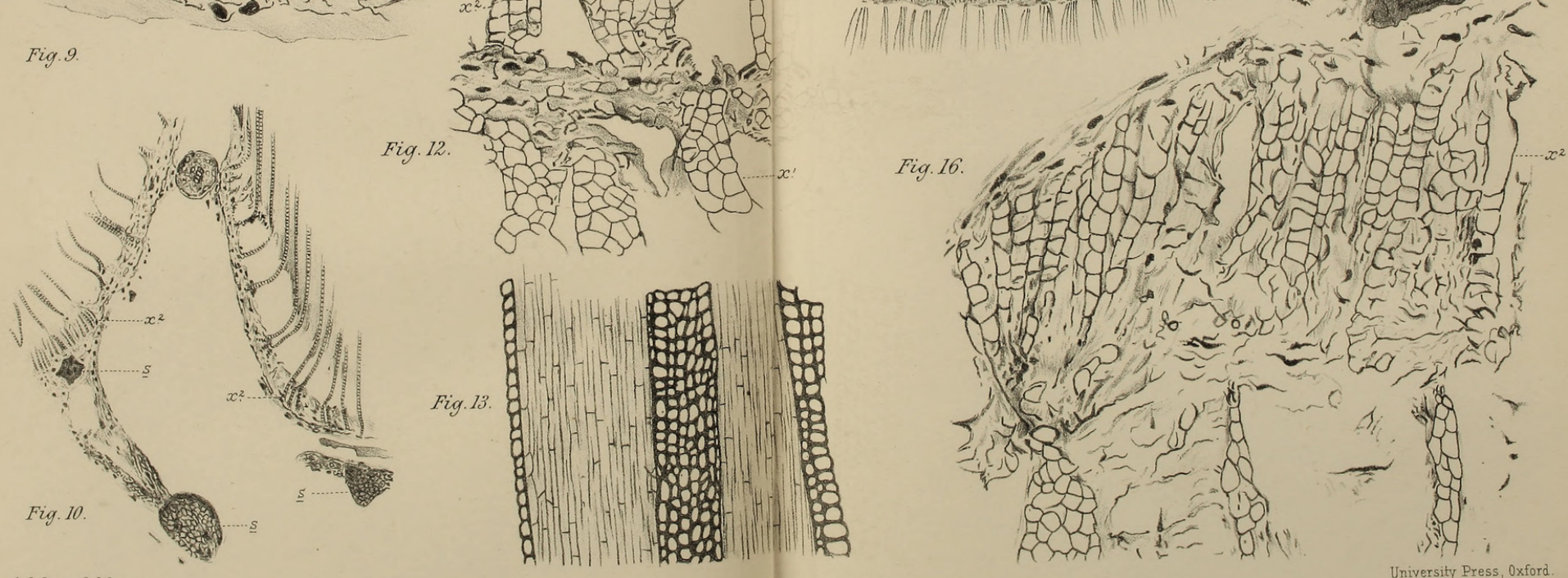

SEWARD. - LYGINODENDRON. 


\section{$2 \mathrm{BHL}$ Biodiversity Heritage Library}

Seward, A. C. 1897. "Contribution to our knowledge of Lyginodendron." Annals of botany 11, 65-86.

https://doi.org/10.1093/oxfordjournals.aob.a088644.

View This Item Online: https://www.biodiversitylibrary.org/item/233542

DOI: https://doi.org/10.1093/oxfordjournals.aob.a088644

Permalink: https://www.biodiversitylibrary.org/partpdf/318453

\section{Holding Institution}

Smithsonian Libraries

\section{Sponsored by}

Biodiversity Heritage Library

\section{Copyright \& Reuse}

Copyright Status: Not in copyright. The BHL knows of no copyright restrictions on this item.

This document was created from content at the Biodiversity Heritage Library, the world's largest open access digital library for biodiversity literature and archives. Visit BHL at https://www.biodiversitylibrary.org. 